\title{
LEADERSHIP SKILLS IN THE DIGITAL AGE: IMPLICATIONS FOR UNIVERSITY BUSINESS SCHOOLS
}

\author{
Lyle Benson \\ MacEwan University Edmonton, Alberta, Canada
}

\begin{abstract}
This exploratory paper focuses its discussion on the $21^{\text {st }}$ century leadership skills graduates of university business schools need to have to be successful in the digital age. Common themes from the leadership literature are first identified. These are then compared with the requirements from: 1 . accrediting agencies for university business schools, 2 . national committees and national councils, and 3. sponsoring foundations. Several common themes about the $21^{\text {st }}$ century leadership skills for the digital age have emerged which have implications for curriculum review and development at universities. Last, questions are asked and suggestions are made for implementation of these common leadership themes in university curriculum content design.
\end{abstract}

Keywords: Leadership skills, Curriculum design, Business schools, Digital age.

DOI: http://dx.doi.org/10.15549/jeecar.v5i2.217

\section{INTRODUCTION}

The digital age has been evolving for the past 70 years since the change from analogue to digital electronics. In the last half of the $20^{\text {th }}$ century this change started the information age with the creation and use of computers and relevant software. By having technology that converted analog into a digital format, it became possible to make identical copies with no loss of information in its transmission, as data was distributed globally across a variety of media such as computers, cellular phones, and the Internet. Digital age technology made an immediate and profound impact in every aspect of people's lives in every country in the world: finance and banking transactions, health care, manufacturing, agriculture, mining, oil and gas, forestry, shopping, travel, personal communication among families and friends, politics, wars, famines, etc. All businesses use digital age technology in some aspect of their operations. The relevance of this topic is the speed of change within the digital age and the corresponding slowness of the response to these changes within university curriculums in preparing graduates for these changes.

The digital age is here, but have university business schools been responding to it? People are still needed to lead these digital organizations. What are the 21st century leadership skills that business executives, managers, and supervisors need to have to deal with the massive changes that are taking place now and in the next 20 years? What curriculum changes do business schools have to do to be certain their graduates are equipped with 21st century leadership skills for the digital age? This will ensure university graduates are ready to assume leadership positions within these digital age organizations.

This exploratory paper will provide a background overview of leadership skills for 
graduate success. After this it will use Jackson and Chapman's (2012) classification as the template to compare the literature on $21^{\text {st }}$ century leadership skills with requirements from: 1 . the skills accrediting agencies require of university business schools, 2 . national committees and national councils skills, and 3. foundations skills. Next, the discussion will focus on common themes that have emerged from this comparison. After this, the implications for curriculum review at university business schools will be addressed.

\section{1st CENTURY LEADERSHIP SKILLS}

For the past 25 years, many government agencies, national commissions, and national councils have created graduate characteristics which employers want, and which are beyond university discipline-specific content knowledge (Table 1). As well, they have recommended universities and colleges prepare students for workforce employability after graduation by developing within them these characteristics.

(ACTE, 2010; Ananiadou \& Claro., 2009; ATC21S, 2010; Bath, Smith, Stein, \& Swann, 2004; Binkley, Erstad, Herman, Raizen, Ripley, \& Rumble, 2010; Conley, 2007; De La Harpe, Radloff, \& Wyber, 2000; Emberg \& Benson, 2010; Finegold \& Notabartolo, 2010; Robley, Whittle, \& Murdoch-Eaton, 2005; Salas, Bedwell, \& Fiore, 2010; Sumsion \& Goodfellow, 2004; \& Voogt \& Roblin, 2010.)

The definition of $21^{\text {st }}$ century leadership skills is a muddled concept because in the literature, the terms skills, attributes, capabilities, competencies, qualities, and traits have been joined with the terms core, generic, life-long learning, non-technical, personal, professional, and transferable to describe sets of student characteristics which educational institutions wish to have embodied in their graduates (Emberg \& Benson, 2010) (see Table 2).
Table1, Government agencies with university student workforce employability characteristics.

\begin{tabular}{|c|c|c|}
\hline Year & Country & Agency \\
\hline 2012 & Canada & $\begin{array}{l}\text { Conference Board of } \\
\text { Canada }\end{array}$ \\
\hline 2012 & $\begin{array}{l}\text { United } \\
\text { States }\end{array}$ & $\begin{array}{l}\text { National Research Council } \\
\text { (NRC) }\end{array}$ \\
\hline 2011 & $\begin{array}{l}\text { United } \\
\text { States }\end{array}$ & $\begin{array}{l}\text { National Research Council } \\
\text { (NRC) }\end{array}$ \\
\hline 2010 & $\begin{array}{l}\text { United } \\
\text { Kingdom }\end{array}$ & $\begin{array}{l}\text { Kennisnet University of } \\
\text { Twente (KUT) }\end{array}$ \\
\hline 2010 & $\begin{array}{l}\text { United } \\
\text { States }\end{array}$ & $\begin{array}{l}\text { Assessment and Teaching } \\
\text { of 21st Century Skills } \\
\text { Project (ATC21S) }\end{array}$ \\
\hline 2010 & $\begin{array}{l}\text { United } \\
\text { States }\end{array}$ & $\begin{array}{l}\text { National Research Council } \\
\text { (NRC) }\end{array}$ \\
\hline 2010 & $\begin{array}{l}\text { United } \\
\text { States }\end{array}$ & $\begin{array}{l}\text { Association for Career and } \\
\text { Technical Education } \\
\text { (ACTE) }\end{array}$ \\
\hline 2010 & $\begin{array}{l}\text { United } \\
\text { States }\end{array}$ & Hewlett Foundation (HF) \\
\hline 2009 & Europe & $\begin{array}{l}\text { Organization for Economic } \\
\text { Cooperation and } \\
\text { Development (OECD) }\end{array}$ \\
\hline 2007 & $\begin{array}{l}\text { United } \\
\text { states }\end{array}$ & $\begin{array}{l}\text { Educational Policy } \\
\text { Improvement Center (EPIC }\end{array}$ \\
\hline 2000 & Canada & $\begin{array}{l}\text { Conference Board of } \\
\text { Canada }\end{array}$ \\
\hline 1999 & $\begin{array}{l}\text { European } \\
\text { Union }\end{array}$ & $\begin{array}{l}\text { European Ministers of } \\
\text { Education Agreement }\end{array}$ \\
\hline 1998 & $\begin{array}{l}\text { United } \\
\text { Kingdom }\end{array}$ & $\begin{array}{l}\text { Confederation of British } \\
\text { Industry }\end{array}$ \\
\hline 1996 & Australia & Dearing Report \\
\hline 1992 & Canada & $\begin{array}{l}\text { Conference Board of } \\
\text { Canada }\end{array}$ \\
\hline 1992 & $\begin{array}{l}\text { United } \\
\text { Kingdom }\end{array}$ & Medical Council \\
\hline 1991 & $\begin{array}{l}\text { United } \\
\text { States }\end{array}$ & $\begin{array}{l}\text { Secretary's Commission } \\
\text { on Achieving Necessary } \\
\text { Skills }\end{array}$ \\
\hline 1991 & Australia & Finn Committee \\
\hline
\end{tabular}


Table 2 . An abridged summary of $21^{\text {st }}$ century leadership skills definitions.

\begin{tabular}{|c|c|}
\hline Year & Definition \\
\hline 2004 & $\begin{array}{l}\text {...those skills, abilities, and personal attributes that can be used within the wide range of } \\
\text { working environments that graduates operate in throughout their lives. Fraser (as cited in } \\
\text { Sumsion \& Goodfellow, 2004.) }\end{array}$ \\
\hline 2004 & $\begin{array}{l}\text {...these student characteristics have come to be accepted as being the skills, knowledge, } \\
\text { and capabilities of university graduates, beyond disciplinary content knowledge, which } \\
\text { are applicable to a range of contexts. Barrie (2004). }\end{array}$ \\
\hline 2007 & $\begin{array}{l}\text {...understandings a university community agrees its students should develop during their } \\
\text { time with the institution and which go beyond the disciplinary expertise or technical } \\
\text { knowledge that has typically formed the core of most university courses. Bowden et al (as } \\
\text { cited in Barrie, 2007). }\end{array}$ \\
\hline 2009 & $\begin{array}{l}\text {...skills essential for employment and for personal development, fulfillment, community } \\
\text { life and citizenship. Gibb (as cited in Cushinahan \& Tafe, 2009). }\end{array}$ \\
\hline
\end{tabular}

Inconsistent terminology in these student characteristics, has resulted in the lack of clarity in defining, using, and understanding the meanings of the terms (Bath, Smith, Stein, \& Swann, 2004; Bridgestock, 2009; Clanchy \& Ballard, as cited in De La Harpe, Cushinahan \& Tafe, 2009; Robley, Whittle, \& Murdoch-Eaton, 2005; and Sumsion \& Goodfellow, 2004). Examples of these student characteristics include: abstract thinking, conflict resolution, creativity, critical analysis, ethics, goal and priority setting, improving own learning, information technology, interpersonal skills, literacy, numeracy, oral communication, presentations, problem-solving, research, selfawareness, teamwork, time management, and writing (De La Harpe et al., 2000; Bath et al., 2004; Robley et al., 2005; and Tariq et al., 2004).

In their research of 500 organizations, Jackson \& Chapman (2012) reviewed and summarized these student characteristics into 19 nontechnical skills required in business graduates with the skill name and the behaviors associated with each skill. These are confidence, core business skills, critical thinking, decision management, environmental awareness, formal communication skills, innovation, leadership, oral communication, organizational skills, performance, personal ethics, professional responsibility, problem solving, self-awareness, self-discipline, work ethic, and working with others.

\section{LIMITATIONS}

In assigning placement of data (Table 3 ), the author had to make decisions about where the data would fit within Jackson and Chapman's 19 characteristics.

This was because in the agencies, national committees, national councils, and accrediting bodies documents, they often used a sentence which described more than one characteristic. For example: "Using media technology to do presentations." This statement would fit under both classifications \#1 and \#6 and thus was assigned to both areas. Second, as this was an exploratory qualitative study there were no preconceived ideas about what would be found or if there were any common themes. Third, even Jackson \& Chapman are not descreet in their clasification. For example: "Skill \#1 includes core business skills, numagecy, and technology." These could be further deliniated into three separate skill areas. After the data was collated it was arranged to show common themes.

\section{COMPARISONS OF $21^{\text {st }}$ CENTURY LEADERSHIP SKILLS ACROSS ORGANIZATIONS}

Because of the skill name and associated behaviours, Jackson and Chapman's (2012) classification is used as the template to compare the literature on $21^{\text {st }}$ century leadership skills with: 1 . the skills accrediting agencies require of university business schools, 2 . national 
committees and national councils criteria of skills, and 3. foundations research on skills. This is the gap in the literature; collating these diverse areas; and then describing the resulting skills. The comparative data is found in Table 3. The table is organized with Jackson and Chapman's skills and definitions on the left. On the top is the year of the report, underneath this the organization or accrediting body, and below this is the author(s) who wrote the report. The organization's full names, report author/s and year are as follows:

a. EPIC - Educational Policy Improvement Center

(Conley, 2007).

b. OECD - Organization for Economic cooperation and Development

(Ananiadou \& Claro, 2009).

c. ACTE - Association for Career and Technical Education

(No referenced author).

d. NRC - National Research Council

(Binkley, Erstad, Herman, Raizen, Ripley, \&

Rumble, 2010). e. HF - Hewlett Foundation

(Finegold \& Notabartolo, 2010).

f. KUT - Kenniset University of Twente

(Voogt \& Pareja Roblin, 2010).

g. IFTF - Institute For The Future

(Anna, Fidler, \& Gorbis, 2011).

h. EFMD (EPAS) - European Foundation for Management Development.

(No referenced author 2017).

i. AACSB - Association to Advance Collegiate Schools of Business.

(No referenced author 2017).

Table 3: Jackson \& Chapman (2012). Comparisons for 21st Century Leadership Skills

\begin{tabular}{|c|c|c|c|c|c|c|c|c|c|c|}
\hline Year & ‘07 & ‘09 & ‘10 & $' 10$ & '10 & '10 & $' 11$ & $' 11$ & '17 & $' 17$ \\
\hline Organization & $\begin{array}{l}\mathrm{E} \\
\mathrm{P} \\
\mathrm{I} \\
\mathrm{C}\end{array}$ & $\begin{array}{l}\mathrm{O} \\
\mathrm{E} \\
\mathrm{C} \\
\mathrm{D}\end{array}$ & $\begin{array}{l}\text { A } \\
\text { C } \\
\text { T } \\
\text { E }\end{array}$ & $\begin{array}{l}\mathrm{N} \\
\mathrm{R} \\
\mathrm{C}\end{array}$ & $\begin{array}{l}\mathrm{H} \\
\mathrm{F}\end{array}$ & $\begin{array}{l}\mathrm{K} \\
\mathrm{U} \\
\mathrm{T}\end{array}$ & $\begin{array}{l}\mathrm{N} \\
\mathrm{R} \\
\mathrm{C}\end{array}$ & $\begin{array}{l}\mathrm{I} \\
\mathrm{F} \\
\mathrm{T} \\
\mathrm{F}\end{array}$ & $\begin{array}{l}\mathrm{E} \\
\mathrm{F} \\
\mathrm{M} \\
\mathrm{D}\end{array}$ & $\begin{array}{l}\text { A } \\
\text { A } \\
\text { C } \\
\text { S } \\
\text { B }\end{array}$ \\
\hline Author (s) & $\mathrm{C}$ & AC & & $\begin{array}{l}\text { BEH } \\
\text { RRR }\end{array}$ & FN & VR & SBF & DFG & EPAS & \\
\hline $\begin{array}{l}\text { Jackson \& Chapman's } \\
2012 \text { Classification }\end{array}$ & & & & & & & & & & \\
\hline Skill \& Behaviour & & & & & & & & & & \\
\hline $\begin{array}{l}\text { 1. Core Business Skills, } \\
\text { Numeracy, Technology }\end{array}$ & & $\mathrm{X}$ & & $\mathrm{X}$ & $\mathrm{X}$ & $\mathrm{X}$ & & $\mathrm{XX}$ & $\mathrm{XX}$ & $\begin{array}{l}\mathrm{XXX} \\
\mathrm{XX}\end{array}$ \\
\hline $\begin{array}{l}\text { 2. Critical Thinking: } \\
\text { Pattern Recognition \& } \\
\text { Conceptualization; } \\
\text { Evaluation }\end{array}$ & $\mathrm{X}$ & $\mathrm{X}$ & $\mathrm{X}$ & $\mathrm{X}$ & $\mathrm{X}$ & & & $\mathrm{X}$ & $\mathrm{XX}$ & \\
\hline $\begin{array}{l}\text { 3. Problem Solving } \\
\text { Analytical/ Convergent } \\
\text { Reasoning; Diagnosing }\end{array}$ & $\mathrm{XXX}$ & $\mathrm{X}$ & $\mathrm{X}$ & $\mathrm{X}$ & $\mathrm{X}$ & $\mathrm{X}$ & & $\mathrm{X}$ & XXX & $\mathrm{XX}$ \\
\hline
\end{tabular}


Table 3: Jackson \& Chapman (2012). Comparisons for 21st Century Leadership Skills (Coninue)

\begin{tabular}{|c|c|c|c|c|c|c|c|c|c|}
\hline $\begin{array}{l}\text { 4. Latagel Thinking/ } \\
\text { Creativity; } \\
\text { Information } \\
\text { Management; Decision } \\
\text { Making; } \\
\text { Decision Management }\end{array}$ & $\begin{array}{l}\mathrm{XXX} \\
\mathrm{X}\end{array}$ & $X$ & $\begin{array}{l}\mathrm{XXX} \\
\mathrm{X}\end{array}$ & $\begin{array}{l}\mathrm{XXX} \\
\mathrm{X}\end{array}$ & $\mathrm{X}$ & & $\mathrm{XX}$ & $\mathrm{X}$ & $\mathrm{XX}$ \\
\hline $\begin{array}{l}\text { 5. Working With Others: } \\
\text { Task Collaboration; } \\
\text { Team Working; Social } \\
\text { Intelligence; Cultural \& } \\
\text { Diversity Management }\end{array}$ & $X$ & XXX & XXX & $X$ & $X$ & $\mathrm{X}$ & $\mathrm{XXX}$ & $\mathrm{XXX}$ & XXX \\
\hline $\begin{array}{l}\text { 6. Formal } \\
\text { Communication Skills: } \\
\text { Public Speaking; } \\
\text { Meeting Participation; } \\
\text { Written Communication }\end{array}$ & $X$ & $X$ & $\mathrm{X}$ & $\mathrm{X}$ & $X$ & $\mathrm{XX}$ & & $\mathrm{X}$ & $X$ \\
\hline $\begin{array}{l}\text { 7. Professional } \\
\text { Responsibility, } \\
\text { Social Responsibility; } \\
\text { Accountability }\end{array}$ & $\mathrm{X}$ & $\mathrm{X}$ & $X$ & $X$ & & $\mathrm{XX}$ & & $\mathrm{XX}$ & $X$ \\
\hline $\begin{array}{l}\text { 8. Leadership: } \\
\text { Project Management; } \\
\text { Performance } \\
\text { Management; Meeting } \\
\text { Management; } \\
\text { Developing Others }\end{array}$ & $\mathrm{X}$ & & & $\mathrm{X}$ & & $\mathrm{X}$ & & & $\mathrm{XX}$ \\
\hline $\begin{array}{l}\text { 9. Self-Awareness } \\
\text { Meta-Cognition; } \\
\text { Lifelong Learning }\end{array}$ & & $\mathrm{X}$ & & & & $\mathrm{X}$ & & & $\mathrm{X}$ \\
\hline $\begin{array}{l}\text { 10. Innovation } \\
\text { Entrepreneurship; } \\
\text { Change Management }\end{array}$ & $X$ & & $\mathrm{X}$ & $\mathrm{X}$ & & & & & \\
\hline $\begin{array}{l}\text { 11. Performance } \\
\text { Efficiency; } \\
\text { Multi-Tasking; } \\
\text { Autonomy }\end{array}$ & $\mathrm{X}$ & & & $\mathrm{X}$ & & & $\mathrm{X}$ & & \\
\hline $\begin{array}{l}\text { 12. Organizational Skills: } \\
\text { Goal \& Task } \\
\text { Management; Time } \\
\text { Management }\end{array}$ & & & & & & $\mathrm{X}$ & $\mathrm{XX}$ & & \\
\hline $\begin{array}{l}\text { 13. Work Ethic: } \\
\text { Drive; Initiative }\end{array}$ & $X$ & & & $\mathrm{X}$ & & & & & \\
\hline
\end{tabular}


Table 3: Jackson \& Chapman (2012). Comparisons for 21st Century Leadership Skills (Continue)

\begin{tabular}{|c|c|c|c|c|c|c|c|}
\hline 14. Personal Ethics & & $\mathrm{X}$ & & & & & $\mathrm{XX}$ \\
\hline $\begin{array}{l}\text { 15. Political Skills } \\
\text { Influencing Others; } \\
\text { Conflict Resolution }\end{array}$ & & & & $\mathrm{XX}$ & & & \\
\hline $\begin{array}{l}\text { 16. Environmental } \\
\text { Awareness } \\
\text { Organizational \& } \\
\text { Commercial Awareness }\end{array}$ & & & & & & $\mathrm{X}$ & \\
\hline $\begin{array}{l}\text { 17. Oral Communication } \\
\text { Verbal Communication; } \\
\text { Giving \& Receiving } \\
\text { Feedback }\end{array}$ & & & & & & $\mathrm{X}$ & \\
\hline $\begin{array}{l}\text { 18. Self-Discipline } \\
\text { Self-Regulation; Stress } \\
\text { Tolagence; Work/Life } \\
\text { Balance }\end{array}$ & & & & & & & \\
\hline $\begin{array}{l}\text { 19. Confidence } \\
\text { Self-efficacy }\end{array}$ & & & & & & & \\
\hline Transdisciplinary & & & & & $\mathrm{X}$ & $\mathrm{X}$ & $\mathrm{X}$ \\
\hline $\begin{array}{l}\text { Flexibility/ } \\
\text { Adaptability }\end{array}$ & $\mathrm{X}$ & $\mathrm{X}$ & $\mathrm{X}$ & & & & \\
\hline Trust & & & & $\mathrm{X}$ & & & \\
\hline Sense Making & & & & & $\mathrm{X}$ & & \\
\hline
\end{tabular}

\section{RESULTS AND DISCUSSION}

From the data, nine major common themes emerged in which 7 to 9 of the 10 organizations had agreement. This is significant as it provides a solid framework for universities to teach essential $21^{\text {st }}$ century leadership skills for executives, managers, and supervisors in the digital age. The data is organized to provide a logical flow of the themes; not in descending order of agreement in themes.

Common theme \#1 was subdivided into three themes. At the core were business skills in which organizations wanted graduates to have basic business knowledge content. This would include fundamental programs that universities provide, such as, accounting, decision sciences, economics, finance, human relations, management, and marketing. The second subtheme was numeracy. Organizations wanted graduates to be able to be proficient with mathematical ability. The third sub-theme was technology. In the digital age, graduates must be able to use current technology and adapt to new technology which has not even been invented.

Common themes \#2, \#3, and \#4 were all related to thinking. The organizations wanted graduates to be able to think critically, solve problems, think creativity, and make decisions. This is an important finding because even in the digital age, people are still required to run organizations, and these leaders must be able to think critically, solve problems, be creative, and make decisions.

Common theme \#5 was working with others: doing tasks, and cultural and diversity management. The organizations wanted graduates in the digital age to be able to work in global organizations, requiring them to get the work done by collaborating with people with different languages, religions, cultures, and ethnic backgrounds.

Common theme \#6 was formal communication skills including public speaking, meeting participation, and written communication. Coupled with theme \#5 the organizations wanted graduates to be able to 
speak in public, write well, and be effective in meetings.

Common theme \#7 was professional responsibility, social responsibility, and accountability. Organizations had a criterion that they wanted graduates to act professionally, be socially responsible, and to hold themselves accountable.

Also, a relevant finding was AACSB and EFMD (EPAS) had a requirement for graduates to be transdisciplinary. This meant that graduates must be able to cross boundaries between disciplines, such as businesses working with agriculture, medicine, chemists, fashion designers, etc. They wanted graduates to have a broader perspective of the opportunities and responsibilities of being leaders in the $21^{\text {st }}$ century.

\section{IMPLICATIONS FOR UNIVERSITY BUSINESS SCHOOLS}

The first implication for curriculum review at university business schools is very positive. From theme \#1, accrediting agencies for university business schools, national committees and national councils, and sponsoring foundations want graduates to have core business knowledge. This includes all the different types of programs universities currently offer, such as, accounting, decision sciences, economics, finance, human relations, management, and marketing. Universities need to continue doing what they are doing in this curriculum area.

The second implication from theme \#1 is numeracy. Organizations wanted graduates to be able to be proficient with mathematical ability. This is a skill that many business graduates only have introductory courses in, if it is not their major, as in decision sciences or accounting. Many graduates are not proficient in data analytics and data mining. In the digital age, data driven decisions are the way important decisions are made; therefore, universities need to consider having more courses and more senior level courses in research methods and statistics required by all graduates in all departments.

The third implication from theme \#1 is technology. Organizations wanted graduates to be able to be proficient in using current technology and adapting to new technology. While many graduates can use their cellphone, text, snap chat, twitter, etc.; many are not able to easily use basic excel, format documents using word, or use statistical packages. This is a skill universities need to reassess and consider including in their curriculums.

The forth implication from themes \#2, \#3, and \#4 are all related to thinking. Accrediting agencies for university business schools, national committees and national councils, and sponsoring foundations wanted graduates to be able to think critically, solve problems, think creativity, and make decisions. Universities already do this, but is this as a tacit concomitant learning of course content? Universities need to assess which thinking skills are formally being taught. For example: one thinking skill is: problems, symptoms, causes, decision criteria, and action plans. Another thinking skill may be compare and contrast. There are many different types of thinking skills and different ways to teach them. Universities need to formally determine in their curriculums what and how they are having graduates become better critical thinkers, problem solvers, creative thinkers, and decision makers.

The fifth implication from theme \#5 is organizations wanted graduates in the digital age to be able to work with others in global organizations, requiring them to get the work done by collaborating with people with different languages, religions, cultures, and ethnic backgrounds in different countries with different time zones. This is especially relevant for universities which have international students. An implication is some courses need to re-structure the group assignments so there is a diversity of students in the teams. The structure can also include team discussions about team members' diverse backgrounds. Just as important is the fact that many universities have group assignments in courses; but are students taught how to work in teams? For example: are they taught: team process theories and practices, how to evaluate individual team member performance, how to give and receive feedback, how to chair meetings, etc.?

The sixth implication from theme \#6 is organizations wanted graduates to be able to speak in public, write well, and be effective in meetings. Most universities are doing a good job of having their graduates learn public speaking through the numerous course presentations they must do and through the written course assignments. As mentioned in the $5^{\text {th }}$ 
implication above universities have students do group assignments but may not teach them how to work in teams. One of the skills required is how to chair effective meetings, create an agenda, and ensure follow-up actions by team members are completed. Often one student will emerge as the team leader and run quasi-formal meetings. This means the rest of the group does not get to take on the leadership role and be responsible for a meeting. Some of the reserved students are happy with this, but they are the ones who most need to take on this leadership role; therefore only a few students are developing this leadership skill.

The seventh implication from theme \#7 is most organizations wanted graduates to act professionally, be socially responsible, and to hold themselves accountable. In the digital age, social responsibility has become a key performance indicator that governments, shareholders, and society hold business leaders accountable for. This is an area that that universities need to describe and measure.

A relevant finding for the eighth implication was not from an agreed upon organization theme; it was from AACSB and EFMD (EPAS), which each had a requirement for graduates to be transdisciplinary. This meant that graduates must be able to cross boundaries between disciplines, such as businesses working with agriculture, medicine, chemists, fashion designers, etc. They wanted graduates to have a broader perspective of the opportunities and responsibilities of being leaders in the $21^{\text {st }}$ century. In a liberal arts university, this will be easier to implement, but in a strictly business university this will be a challenge.

\section{CONCLUSIONS}

The $1^{\text {st }}$ conclusion is most University Business Schools are adequately preparing their graduates for leadership positions in the digital age in core business knowledge such as accounting, decision sciences, economics, finance, human relations, management, and marketing.

The 2 nd conclusion is there is a core set of $21^{\text {st }}$ century leadership skills which universities can develop within their curriculums to prepare students for the digital age. These skills are:

1. Thinking Skills: critical, creative, and reflective thinking to prepare students to make decisions to solve problems.
2. Writing Skills: effectively communicating thoughts and ideas in a written format to others.

3. Self-Skills: act professionally, be socially responsible and hold oneself accountable for one's choices and actions.

4. Numeracy Skills: mathematical ability, research methods, and use of statistics for data analytics and data mining to help make informed decisions to solve problems.

5. Team Diversity Skills: to work in global

organizations to get tasks done by

collaborating with people with different

languages, religions, cultures, and ethnic

backgrounds in different countries across

different time zones.

6. Communication Skills: effectively

conveying thoughts and ideas in a verbal

format when speaking in public.

7. Meeting Skills: creating agendas, chairing meetings, and ensuring follow-up actions by team members are completed.

8. Transdisciplinary Skills: to cross boundaries between disciplines by bringing theories and practices from one discipline and applying them in another discipline.

The 3rd conclusion suggests that universities need to include more of these skills within all their business departments and that graduates need higher levels of competence in these leadership skills to be successful in the digital age.

The 4th conclusion is universities implement quantitative and/or qualitative research-based studies to provide evidence of students learning these $21^{\text {st }}$ century leadership skills (Coates, 2009; Emberg \& Benson, 2010), as this is required by accrediting bodies, such as AACSB and EFMD (EPAS).

Future lines of research will involve a more systematic analysis of the government agencies with university student workforce employability characteristics. (Table 1 ) with the intent of finding a manageable core group of skills which can be defined, measured, and easily integrated in university curriculums.

\section{REFERENCE}

AACSB International. (Sept.2017). The

Association to Advance Collegiate Schools of Business: Eligibility Procedures and Accreditation Standards for Business Accreditation.

ACTE. (2010). Association for Career and Technical Education. What is Career Ready? 
Alexandra, VA: Available:

http://dpi.wi.gove/oea/pdf/crpaper.pdf

ATC21S. (2010). Assessment and Teaching of

21st Century Skills Project.

http://atc21s.org/index.php/resources/white papers/\# item1.

Ananiadou, K. and Claro, M. (2009). 21st century skills and competences for new millennium learners in OECD countries. Paris:

Organization for Economic Cooperation and Development. Available: http://www.oecdilibrary.org/education/21st-century-skills

Bath, D., Smith, C., Stein, S. \& Swann, R. (2004). Beyond mapping and embedding graduate attributes: bringing together quality assurance and action learning to create a validated

and living curriculum. Higher Education Research \& Development, 23(3), 313-328.

Binkley, M., Erstad, O., Herman, J., Raizen, S., Ripley, M., and Rumble, M. (2010). Defining 21st Century Skills. White Paper commissioned for the National Research Council. (2012). Education

Conley, D. T. (2007). Redefining College Readiness. Eugene, OR: Educational Policy Improvement Center (EPIC). https://www.epiconline.org/files/pdf/Redefi ningCollegeReadiness.

Davies, A., Fidler, D., \& Gorbis, M. (n.d.). Future Work Skills 2020. IFTF: The Institute for the Future.www.iftf.org Institute for the Future for the University of Phoenix Research Institute.

De La Harpe, B., Radloff, A., \& Wyber, J. (2000). Quality and generic (professional) skills. Quality in Higher Education, 6(3), 231-243.

Emberg, S, \& Benson, L. (2010). Integrating Professional skills into a Bachelor of commerce program: A case study. In Proceedings of $17^{\text {th }}$ EDiNEB Conference (June 09-12), London, United Kingdom.

EFMD (EPAS). (2017). European Foundation for Management Development.

Finegold, D., and Notabartolo, A.S. (2010). 21st Century Competencies and their Impact: An Interdisciplinary Literature Review. Paper commissioned for the NRC Project on Research on 21st Century Competencies: A Planning Process on Behalf of the Hewlett Foundation.http://www7.nationalacademies .org/bota/Finegold_Notabartolo_Impact_Pap er.pdf.

Jackson, D. \& Chapman, E. (2012). Non-technical competencies in undergraduate business degree programs: Australian and UK perspectives. Studies in Higher Education, 37(5), 541-567.

Jackson, D. \& Chapman, E. (2012). Non-technical competencies in undergraduate business degree programs: Australian and UK perspectives. Studies in Higher Education, 37(5), 541-567.

National Research Council. (2012). Education for Life and Work: Developing Transferable Knowledge and Skills in the 21st Century. Committee on Defining Deeper Learning and 21st Century Skills, James W. Pellegrino and Margaret L. Hilton, Editors. Board on Testing and Assessment and Board on Science Education, Division of Behavioral and Social Sciences and Education. Washington, DC: The National Academies Press.

Robley, W., Whittle, S., \& Murdoch-Eaton, D. (2005). Mapping generic skills curricula: Outcomes and discussion. Journal of further and Higher Education, 29(4), 321-330.

Salas, E., Bedwell, W.L., and Fiore, S.M. (2011). Developing the 21st Century (and Beyond)

Workforce: A Review of Interpersonal Skills and Measurement Strategies. Paper prepared for the NRC Workshop on Assessing 21st Century Skills. Available: http://www7.nationalacademies.org/bota/2 1st_Century_Workshop_Salas_Fiore_Paper.p df.

Sumsion, J. \& Goodfellow, J. (2004). Identifying generic skills through curriculum mapping: a critical evaluation. Higher Education Research \& Development, 23(3), 329-346.

Voogt, J., and Pareja Roblin, N. (2010). 21st Century Skills Discussion Paper. Report prepared for Kennisnet University of Twente. 


\section{ABOUT THE AUTHORS}

Lyle Benson: bensonl@macewan.ca

Dr. Lyle Benson is a 30-year faculty member in the Bachelor of Commerce Program at MacEwan University. His area of research interest is Wholistic Leadership Development. This includes undergraduate development of leadership skills, team member effectiveness skills, professional skills, peer coaching skills, and negotiating skills. He is also interested in undergraduate self-confidence development in the preceding areas. He created the following leadership programs: Leaders In Action, Make Contact, and Alberta's Future Leaders in which over 50 thousand youth have participated. Dr. Benson has given 27 academic presentations, 15 invited scholarly presentations, 27 professional presentations, and conducted 119 professional training events. 